\title{
The Problematic Aspects of Cultural Policy in Modern Tuva
}

\author{
Ekaterina K. Karelina* \\ Novosibirsk State Glinka Conservatoire \\ 31 Sovetskaia Str., Novosibirsk, 630099, Russia
}

Received 11.12.2017, received in revised form 22.01.2018, accepted 06.02.2018

\begin{abstract}
The article is devoted to the analysis of the cultural politics in Tuva and is focused on the problematic aspects of its current development. It is the result of reflection on personal participation in the cultural policy making in the Tyva Republic, followed by the report and its subsequent discussion (within the Forum "Tuva of Future: Strategy for Change", 28-30 June 2017, Kyzyl) through the application of historical-comparative, structural-typological and participant observation's methods. According to the author, a major challenge for the development of culture industry of Tuva is that in the Soviet period it was the institutional model chosen for regional cultural development, while the region experiences the lack of human resources. Ethnic culture of the post-Soviet stage in the Tuvan history is characterized by the self-isolation concerning the value aspect. The implementation of the cluster institutional models and the effective use of the Tuva cultural brand, which is an eco-exo-ethnocultural synthesis, can contribute to the solution of the cultural policy problems. The research results can be applied in the development of concepts and Republican target programs of the Tuva cultural development. The prospect may be finding the optimal balance of conservative and innovative tendencies. The imbalance between ethnic culture and national culture in the contemporary cultural life of the Republic should be oriented towards the national (Russian) identity and its understanding.
\end{abstract}

Keywords: Tuva, the Tyva Republic, cultural policy, cultural sector, institutional model, cluster model, cultural brand, ethnic identity, national identity.

DOI: 10.17516/1997-1370-0217.

Research area: culturology.

\section{Introduction}

Specificity of Tuva culture is largely determined by the region late inclusion in the orbit of the all-Russian cultural life, which is determined by the historical conditions ${ }^{1}$. Since the era of the Tuvan People's Republic (TPR) culture has been one of the priority sectors of the Tuva social and economic development.
However, the issues of cultural policy in Tuva have not yet become an object of special scientific research, even though they have been repeatedly and publicly discussed. In June 2017, within the framework of the "Tuva of Future: Strategy for Change" Forum held by the Government of the Tyva Republic I prepared an analytical report "Culture of Tuva: Current State and Development

(C) Siberian Federal University. All rights reserved

* Corresponding author E-mail address: ye_karelina@mail.ru 
Prospects for the Period until 2030", read in the section "The Role of Culture in Human Capital Bringing" and discussed with distinguished figures of culture and art of Tuva, managers, practitioners and culture studies scholars.

The problems of cultural policy in Russia have been extensively studied in various works of Russian cultural scientists, e.g.: dissertational researches by E.V. Kuznetsova (Kuznetsova, 1999), G.N. Chumikova (Chumikova, 2004), A.V. Solov'ev (Solov'ev, 2004), the textbook by V.S. Zhidkov and K.B. Sokolov (Zhidkov, 2001), the articles by N.A. Mikheeva (Mikheeva, 2006), S.S. Zagrebin (Zagrebin, 2008), etc. I shall also name special studies on the problems of regional cultural policy, in particular, the monograph "Politics and Culture in the Russian Province" (published in Saint-Petersburg in 2001); dissertational researches by L.E. Kovaleva (Kovaleva, 2012) and E.I. Lobyneva (Lobyneva, 2016).

\section{Statement of the Problem and Methods}

The article is intended to reveal the problematic aspects of the cultural policy in modern Tuva with the subsequent analysis and drawing up an optimal development strategy. The object of our work is the modern culture in Tuva, and the subject is the problematic aspects of the cultural policy in the Republic. Conceptual grounds for the research are the ideas of Russian culture studies scholars: the thoughts of A.Ia. Flier (Flier, 2000), the typology of cultures proposed by A.V. Kostina (Kostina, 2009), the concept of ethno-cultural identity developed by I.V. Malygina (Malygina, 2017).

Like most researchers, I regard the concept of "cultural policy" in two ways - in a broad and narrow (instrumental) sense, namely: 1) as a set of views and actions on the socio-cultural development of society ${ }^{2}$, and 2) as a system for managing cultural processes. The perspective of my research is more closely connected with the second interpretation and is focused on the development of culture as an industry.

My views are similar to G.N. Chumikova's position (Chumikova, 2004), who sees the main task of state cultural policy as determined by the promotion of the process of intergenerational transfer of cultural values, i.e. education of the national culture members. In a polyethnic state, the tasks of cultural policy are hindered by the need to preserve and transmit both national and ethnic cultural values that interact in a complex way as described by A.V. Kostina (Kostina, 2009).

Based on my own participation in the cultural policy of the Tyva Republic (including managerial experience), materials and subsequent discussion of the above-mentioned report with the help of a number of methods (comparativehistorical, structural-typological and participant observation) I came to some conclusions formulated in the present article.

\section{Discussion}

The main problem of the development of the cultural sector in Tuva, first of all, seems to be the original discrepancy between the small number of human resources in the region (about 310 thousand people now and even half of that number less than 50 years ago) and the chosen institutional model of culture (in fact, Eurocentric), which has been originally designed for another socio-cultural situation. Such a model may be implemented effectively only in a large national autonomy (for example, in Tatarstan or Buryatia) or in a metropolitan city (such as Novosibirsk or Krasnoyarsk). This model is a legacy of Soviet cultural policy, a common model for the peoples and ethnic groups of the former USSR, which vary in their cultural identity. This model certainly has its 
advantages, as it fully enough ensures both the transfer of global and national cultural values in any society, and bringing up specialists for the societal functioning and self-development. It is not accidental that many national regions of the former USSR enjoyed not only the dramatic, but also the opera and ballet theatres, specialised museums and libraries, the centres of folk art, philharmonic societies, educational institutions of all levels which trained the professionals for the cultural sector; the ethnic writers, artists, composers and actors were actively supported by the state with the creation of unions and the encouragement of ethnic works created in the genres of academic art.

However, despite the merits of the discussed model of culture creation, one must recognize its inflexibility, and at times inadequateness to the cultural context in which it was implemented by the politicians' will and decisions ${ }^{3}$. The proof of these disadvantages is the processes taking place in the contemporary cultural space of the CIS countries, as well as in Russia. For example, in Central Asia and a number of regions of Russia, new forms that foster ethno-cultural values have significantly outshone the sphere of academic (European) art. This is a result of the processes of the ethnic cultures' revival, which, according to A.V. Kostina, "begin to take on national cultures, establishing complex and contradictory relations with them" (Kostina, 2009: 50). Tuva may also show a dramatic example here. Analysis of cultural life in the Republic in recent decades demonstrates a considerably increased share of activities and art works that advance ethnic cultural values. Ethnic culture in modern Tuva, to a certain extent, has squeezed the culture of the national (general Russian) one, and some ethno-artistic traditions find their embodiment in modern forms of mass culture, often limiting the presence of world culture. There is an imbalance meaning that the population of modern Tuva sometimes does not perceive the works of the all-Russian culture as "their own", that is why the repertoire of performing organizations has a corresponding bias towards the local works ${ }^{4}$. There are several reasons for this phenomenon, and, in our opinion, several of them are objective: 1) the dynamics of socio-cultural and migration processes, thanks to which the share of indigenous population in the republic has increased in recent years (now it is more than $80 \%$ of the total number of inhabitants), and the inflow of rural population from the districts into Kyzyl; 2) a good command of the native language in the region (which is spoken by more than $90 \%$ of the Tuvans), the dominance of the native language in everyday life and in educational practice; 3) territorial remoteness and geographical isolation of Tuva, which do not facilitate the intensification of cultural contacts with other Russian regions; 4) Tuva's relatively late inclusion into the territories of Russia and the "unfinished state" of the cultural creation model chosen in the last century, many elements of which have never been realised ${ }^{5}$.

Indicative was the reaction of Tuvan experts during the discussion of my report where the culture state in Tuva was considered as an object of SWOT analysis. The colleagues agreed that Strengths could include: the great potential of the region as a eco-tourism and ethno-tourism destination; revival of cult and ethnic traditions; preservation and development of traditional kinds of folk art (oral, poetic, musical, decorative and applied); the abundance of specialists specialised in many types of culture and art; training of personnel for the industry in the specialized educational institutions; existing cultural ties with other regions; experience of interregional and international projects. However, the thesis that Weaknesses include, among other things, the mono-national character of the cultural environment and the underestimation of the cultural identity of the kindred peoples was 
met very emotionally. The audience insisted on exclusivity, "otherness", the special successes of the Tuvan culture in comparison with neighbouring peoples (especially concerning the art of throat singing). Self-absorption of culture in the value aspect, which we observed 10 years ago, while conducting research to study the work of the Tuva National Orchestra, is still preserved. In our opinion, this factor, which earlier marked a surge of ethnic self-awareness (a general trend within the whole post-Soviet space), cannot be considered positive at present, rather, it indicates the cultural stagnation ${ }^{6}$.

One aspect of the problem of ethnic selfidentification can be a story with a modern anthem of Tuva, which is a song of the ethnic Tuvans from the Mongolian sumon (a type of administrative district used in China, Mongolia, and Russia) Tsengel "Men - tyva men" ("I am a Tuvan"). The song was initially treated as a symbol of unofficial culture, as the bright concert performance of the newly created Tuva National Orchestra. This song appealed to the public very much. Having entered the official culture as an anthem of the republic in 2011 (moreover, it was done by the belligerent solution of the authorities, contrary to the opinion of specialists and the public), the song was rethought and spiritually rejected by most of the Tuvan population as "a foreign, Mongolian song".

The contradictoriness and bias in the apprehension of what is a part of ethnic culture and what is not determines specific tasks for the development of the regional cultural policy strategy. There is a good reason for that the first point of the resolution on the results of this section's work at the 2017 Forum was the following recommendation to the Ministry of Culture of the Republic: "A special program shall be developed to save the standard forms and samples of traditional Tuvan culture for the purpose of the national spiritual revival"». Cultural policy in the conditions of a multinational and multiconfessional state always ought to be aimed at heightening the need for cultural interaction, which, in turn, is to overcome national and confessional conflicts and social disunity.

One of the problems complicating the development of the Tuvan culture as an industry is the established misconception on the part of the Republic authorities, who mixing the functioning of culture as the concept and the functions of cultural institutions (the correspondent organizations), in this connection, the institutions and cultural workers are get additional responsibilities (which in fact are the duties of the bodies of law enforcement, guardianship, education, and health and social development agencies combined). Perhaps the roots of this view lie in the history of the Tuvan statehood, since in the 1920s-1930s the Ministry of Culture of the TPR was in charge of several branches of the social sphere at the same time. It was to regulate not only culture as it is, but also education, healthcare and science. Many modern managers in Tuva demonstrate, on the contrary, a narrow view bout the functions of cultural institutions only as leisure ones. The services of culture as an industry should not be confused with the work of other branches of the social sphere, although they certainly intertwine and interact, contributing to the overall result of social development.

To implement an effective cultural policy it is important to understand what general mission each direction and institution of culture has ${ }^{10}$. With the broad general services of cultural institutions (including communicative, gnosiological, axiological, educational and propagandistic, creative-heuristic, hedonistic and educational functions), unawareness of the mission, and, as a result, incorrect prioritization and use of human and creative potential do not allow the authorities to concentrate existing resources in the right way. 
In the real conditions of Tuva, it is necessary to take into account the contradictions noted above and seek compromise for achieving different tasks of socio-cultural development and meeting the various cultural needs of the population. The way out is seen in thinking over and implementing the cluster institutional models, for example: 1) the theatre and concert cluster, uniting the Tuvan Music and Drama Theatre named after. V.Sh. Kok-ool, the Puppet Theatre, the Tuvan State Philharmonic Hall, the song and dance ensemble "Sayany", the brass band of the Government of the Tyva Republic, cinema organizations, the creative unions of composers, theatre and concert workers; 2) the museum and library cluster, uniting the National Museum named after Aldan-Maadyr, the National Library named after A.S. Pushkin, museums, the network of libraries, the archival agency, the creative unions of writers and artists; 3) the cultural and educational cluster, uniting the Kyzyl College of Arts named after A.B. Chyrgal-ool, the Republican School of Arts named after R.D. Kendenbil, the Republican Centre for Continuing Education, the network of children's art schools, the choral society; 4) the ethno-socio-cultural cluster uniting the House of Folk Art, the Centre of Tuvan Traditional Culture and Crafts, the Centre of Russian Culture, the International Science Centre "Khoomei", the network of club institutions, the creative unions of khoomei performers and craftsmen who make musical instruments ${ }^{11}$.

The challenging issues which require a serious discussion and a balanced decision are the following ${ }^{12}: 1$ ) which institution can take on the responsibility for being an organizing centre in each of the clusters; 2) the blurring of the status of the Tuvan National Orchestra (Is it a professional or a folklore orchestra? Should the orchestra enter the theatrical concert cluster and then logically join the Philharmonic Hall or should it keep its status as the largest folk band of Tuva?); 3) which cluster should the created Khoomei Academy enter (the educational or the ethno-cultural one?). The answers here depend on the definition of the clusters' mission. The organization of the cluster as a whole system based on the principle of the missions' similarity, with a common development strategy and agreed work plans for the separate institutions, with a single management centre (possibly a joint funding stream), with interchangeable and combinable elements, in our view, could be a solution for the task to adapt the existing institutional system to the real cultural life in modern Tuva ${ }^{13}$.

It is essential to realize that the regional cultural identity is a brand that largely determines the attractiveness of Tuva in the Russian and world community. The specifics of this brand is the concurrent combination of different factors: the geographical remoteness and diversity of wildlife, the predominance of the indigenous population and the well-preserved traditional culture, the elaborate ancient beliefs and folk art combined with the most modern forms of mass culture. In comparison with other regions of the Russian Federation, in Tuva the academic forms of art and cultural life have been developed to a much lesser extent than the traditional and modern forms. Therefore, the Tuvan culture can be regarded as a kind of eco-exo-ethno-cultural synthesis.

In the kozhuuns (kozhuun is "raion", a unit in the system of the administrative division), the way of zone cultural branding seems to be quite effective. On the basis of the culture departments in kozhuuns and the leading culture institutions in sumons (municipalities) it is possible to create clusters united by the common goal of the local cultural brand promotion (which will also contribute to the development of the region's tourist attractiveness). The examples of local brands are stone-cutting art, a local style of throat singing (khoomei), a culture of Old Believers, 
a Buddhist temple (khuree), the birthplace of famous cultural personalities of Tuva, a local museum or a library, a memorable performing team, etc. One of cases aimed at creation of the local cultural brand is "Ustuu-Khuree", the International Festival of Live Music and Faith, which has been held in Chadaan regularly since 1999, bringing together musicians of different style directions and from different countries to gather in the countryside under the walls of the Buddhist temple.

The International Festival of Tuvan Lamb, held in August 2017, which successfully combined several different components: gastronomic, cultural and ecological, is also an example of the fruitful use of the cultural brand. The festival was held in the picturesque surroundings as a part of the national holiday Naadym and united Tuvan chefs, masters from Ufa, Novosibirsk, Minusinsk, Mongolia and China. Besides, the festival offered a cultural program and was covered in the John Warren TV program "Let's Go, Let's Eat!" (NTV channel), where lamb and khoomei were presented in the culinary and musical performance by striking Aian Shirizhik. The festival became the best advertisement not only for an environmentally friendly product, but also for Tuvan traditions, fully embodying the ideal of eco-exo-ethno-cultural synthesis, which was discussed above.

\section{Conclusion}

For the development of the cultural sector in Tuva it is vital to take into account the sociodemographic factors of recent years: 1) the high birth rate in the Republic can be viewed as a positive trend for the development of cultural and educational projects and the upbringing of a new generation that will know the ethnic traditions, cherish general Russian cultural values and will be ready to integrate into the world cultural space; 2) the noticeable migration of rural residents to the capital of the Republic, unfortunately, does not contribute to the traditional culture preservation and negatively affects the level and development of urban culture, which complicates the tasks of general cultural education of the population.

Eventually, the prospects for the development of the sphere seem to be the optimal balance of culture-saving and innovative measures. For example, developing the Tuvan throat singing (khoomei) as a professional contemporary performing art, the Khoomei Academy at the same time shall ensure saving its authentic types and local varieties; this task should become the leading one for the Khoomei Academy, the project of whose creation is being actively discussed by the authorities and cultural community.

At the same time, in our opinion, measures to affirm ancestral and ethnic identity should not be the priority of the cultural policy in modern Tuva: everyone has to admit that at the beginning of the new millennium these searches were successful, they were repeatedly rethought, perceived and experienced emotionally and reflected in stable behavioural models. The topical issue is that the Tuvans should comprehend their general national (all-Russian) identity ${ }^{14}$, and this issue, as it seems, should become the main vector of the modern cultural policy in Tuva.

\footnotetext{
In 1914, the Russian protectorate was established in the Uryanghai Region (the former name of Tuva, which had been a part of the Chinese Qin empire from the mid-18 $8^{\text {th }}$ century), then followed a short period of an independent state (Tannu Tuva-TPR: 1921-1944), in 1944 Tuva became a part of the USSR (the last from all national autonomies) and got the name of Tuva Autonomous Republic, and since 1961 - the Tuva ASSR), since 1991 - the Tyva Republic as a part of the Russian Federation.

2 In the interpretation of A.Ia. Flier, cultural policy is a kind of "conscious adjustment of the general content of the national culture" (Flier, 2000: 407).

3 As a result, on the example of Tuva and neighbouring regions (Khakassia and the Altai Republic) we can observe how the chosen model is inevitably modified in concrete ethno-historical conditions. This situation also reveals the potential adaptive capacity of cultural phenomena.
} 
4 According to personal observations, the local audience often remains emotionally indifferent to the performances of artists from other regions, to the Russian musical repertoire, to works of European and world art, clearly preferring Tuvan music (albeit of low artistic level) and works in their native language.

5 The "unfinished state" (incompleteness) of the existing institutional system, the lack of a number of its key links (a specialized university, some Opera and Ballet Theatre, a professional choir, etc.) have an effect not only on the academic forms of culture (low level of a number of genres and arts, lack of narrow specialists - museum experts, art critics, sound engineers, etc.), but also on the development of traditional forms of folk art (in particular, there are problems connected with the organization of the Khoomei Academy).

${ }_{6}$ Here I agree with the opinion of the culture studies scholar A.K. Kuzhuget, who argues that the Tuvan culture "cannot develop autonomously, without a dialogue with other cultures" (Kuzhuget, 2006: 267).

7 The musicological analysis of this song is not the aim of this article, though its melody is not of the Tuvan nature in spite of the declarations in the text.

8 These were culture studies scholars who insisted on this, noting that "the Tuva peoples are ignorant of their history and traditional culture" (cited from the Resolution on the results of the section's work).

9 An example of how the socio-cultural effectiveness of the institution could be reduced to its leisure function only is the cinema "Naiyral", which due to its exceptional location in the Tuvan capital may have been successfully used as a cinema-concert complex.

10 Some of the mission objectives for certain cultural institutions in the Tyva Republic: 1) The National Museum named after Aldan-Maadyr: preservation of the Tuvan material and cultural heritage; 2) The Tuvan Music and Drama Theatre named after V.Sh. Kok-ool: the education of public consciousness by means of the art synthesis (the theatre as a "school of life comprehension"); 3) The Tuva State Philharmonic Hall: generation of social needs in academic music; 4) Republican School of Arts named after R.D. Kendenbil: pre-professional preparation of gifted children (the personnel potential for the sphere); 5) The Centre of Tuvan Traditional Culture and Crafts: saving and development of the regional ethno-cultural identity.

11 Each cluster can include leading republican institutions and state performing organizations, a network of relevant institutions, as well as public creative associations, which in fact work alongside with performing organizations and cultural institutions.

12 Let us remark that the preliminary discussion of these issues within the forum section was very emotional, which also proves that the issues raised are very acute.

13 It is also useful to revise the types of the Tuvan club institutions, which in some cases can function as theatre-concert or cinema-concert complexes, multicultural or ethno-cultural centres, rather than as centres for organized leisure.

14 For many centuries, the cultural consciousness of the Tuvans had been associated with the peoples of Central Asia, the related ethnoses of the Altai-Sayan region, which means that the Russian context for the Tuva mentality is relatively new due to the historic reasons. In this regard, there is a fear that Tuva's entry into Russia became a political (formal) act only, not backed up by the changed spiritual apperception.

\section{References}

Chumikova, G.N. (2004). Kontseptual'nye osnovaniia kul'turnoi politiki $i$ deiatel'nosti uchrezhdenii kul'tury v sovremennoi Rossii: diss. ... kand. kul'turologii [Conceptual bases of cultural policy and activities of cultural institutions in modern Russia: Dissertation for the academic degree of a Candidate of Culture Studies]. Moscow, $194 \mathrm{p}$.

Flier, A.Ia. (2000). O novoi kul'turnoi politike Rossii [On the new cultural policy in Russia], In Kul'turologiia dlia kul'turologov [Culturology for culture studies scholars], 407-424. Moscow.

Kostina, A.V. (2009). Natsional'naia kul'tura - etnicheskaia kul'tura - massovaia kul'tura: "Balans interesov" v sovremennom obshchestve [National culture-ethnic culture-mass culture: the "Balance of interests" in modern society]. Moscow, Knizhnyi dom "LIBROKOM", 216 p.

Kovaleva, L.E. (2012). Kul'turnaia politika razvivaiushchegosia regiona kontsa XX-nachala XXI veka (na primere Khanty-Mansiiskogo okruga - Iugry): diss. ... kand. kul'turologii [Cultural policy of the developing region at the end of the 20 $0^{\text {th }}$ - beginning of the $21^{\text {st }}$ century (on the example of Khanty-Mansi Autonomous District (Okrug) - Yugra): Dissertation for the academic degree of a Candidate of Culture Studies]. Nizhnevartovsk, 155 p.

Kuzhuget, A.K. (2006). Dukhovnaia kul'tura tuvintsev: struktura i transformatsiia [The spiritual culture of Tuva: structure and transformation]. Kemerovo, KemGUKI, 320 p.

Kuznetsova, E.V. (1999). Kul'turnaia politika Rossii: teoriia, istoriia i sovremennost': diss. ... kand. kul'turologii [Cultural policy of Russia: theory, history and modernity: Dissertation for the academic degree of a Candidate of Culture Studies]. Moscow, $131 \mathrm{p}$. 
Lobyneva, E.I. (2016). Gosudarstvennaia kul'turnaia politika v SSSR v 60-80-e gg. XX v. (na primere Krasnoiarskogo kraia): diss. ... kand. kul'turologii [State cultural policy in the USSR in 1960-80s (on the example of Krasnoyarsk Krai): Dissertation for the academic degree of a Candidate of Culture Studies]. Krasnoyarsk, 165 p.

Malygina, I.V. (2017). Dinamika etnokul'turnoi identichnosti: mirovye trendy i rossiiskaia spetsifika [The dynamics of ethnocultural identity: global trends and Russian specifics], In Kul'tura kul'tury [Culture of culture], 2, available at: http://cult-cult.ru/dinamika-etnokuliturnoj-identichnosti/ (accessed 25 October 2017).

Mikheeva, N.A. (2006). Kul'turnaia politika gosudarstva kak instrument upravleniia sotsial'nokul'turnoi sferoi [State cultural policy as a management tool of socio-cultural sphere], In Analitika kul'turologii [Analytics of cultural science], 2(6). available at: http://www.analiculturolog.ru/journal/ archive/item/1764-культурная-политика-государства-как-инструмент-управления-социальнокультурной-сферой.html (accessed 25 October 2017).

Ryzhenkov, S., Liukhterkhand-Mikhaleva, G., Kuz'min, A. (2001). Politika i kul'tura v rossiiskoi provintsii. Novgorodskaia, Voronezhskaia, Saratovskaia, Sverdlovskaia oblasti [Politics and culture in the Russian province. Novgorod, Voronezh, Saratov, Sverdlovsk Oblasts]. Moscow-Saint Petersburg, $267 \mathrm{p}$.

Solov'ev, A.V. (2004). Sotsiokul'turnaia politika v period rossiiskikh preobrazovanii na rubezhe XX-XXI vekov: teoreticheskie aspekty: diss. ... kand. kul'turologii [Socio-cultural policy during the period of Russian reforms at the turn of the 20th - 21 st centuries (theoretical aspects): Dissertation for the academic degree of a Candidate of Culture Studies]. Moscow, $169 \mathrm{p}$.

Zagrebin, S.S. (2008). Kul'turnaia politika v sovremennoi Rossii [Cultural policy in modern Russia], In Voprosy kul'turologii [Issues of Culturology], 3, 33-35.

Zhidkov, V.S., Sokolov, K.B. (2001). Kul'turnaia politika Rossii: teoriia i istoriia. Uchebnoe posobie dlia vuzov [Cultural policy in Russia: theory and history. Textbook for high schools]. Moscow, Akademicheskii Proekt, 592 p.

\title{
Проблемные аспекты культурной политики в современной Туве
}

\author{
Е.К. Карелина \\ Новосибирская государственная консерватория \\ им. М.И. Глинки \\ Россия, 630099, Новосибирск, ул. Советская, 31
}

Предлагаемое исследование посвящено анализу культурной политики Тувы и сконщентрировано на проблемных аспектах её развития на современном этапе. Работа является результатом осмысления личного опыта участия в культурной политике Республики Тыва, материалов доклада и последующего его обсуждения (в рамках Форума «Тува будущего: стратегия перемен», 28-30 июня 2017 г., г. Кызыл) на основе применения сравнительно-исторического, структурно-типологического и метода включенного наблюдения. Основная проблема развития отрасли культуры Тувы видится автору в изначальном несоответствии избранной 
в советский период институциональной модели культурного строительства с недостаточным объемом людских ресурсов региона. Для этнической культуры постсоветского этапа истории Тувы характерна замкнутость в изенностном отношении на себе самой. Решению проблемных аспектов культурной политики могут способствовать реализация институциональных моделей кластерного типа и эффективное использование культурного бренда Тувь, который представляет собой эко-экзо-этнокультурный синтез. Результать исследования могут найти применение при разработке концепциий и республиканских ичелевых программ культурного развития Тувы. Перспективы развития отрасли видятся в оптимальном балансе охранительных и инновационных тенденций. Дисбаланс соотнотения этнической и нац̧иональной культуры в современной культурной жизни республики следует скорректировать нацеленностью в сторону осмысления национальной (общероссийской) идентичности.

Ключевые слова: Тува, Республика Тыва, культурная политика, отрасль культуры, институцุиональная модель, кластерная модель, культурный бренд, этническая идентичность, национальная идентичность.

Научная специальность: 24.00.00 - культурология. 